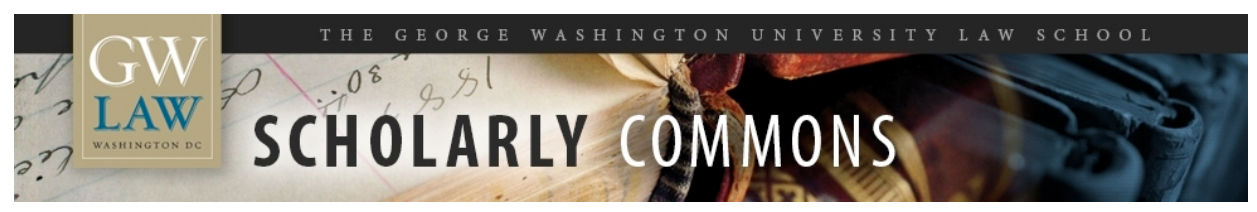

\title{
Jus Ad Bellum, Values, and the Contemporary Structure of International Law
}

\section{Sean D. Murphy}

George Washington University Law School, smurphy@law.gwu.edu

Follow this and additional works at: https://scholarship.law.gwu.edu/faculty_publications

Part of the Law Commons

\section{Recommended Citation}

Sean D. Murphy, Jus Ad Bellum, Values, and the Contemporary Structure of International Law, 41 Journal of Religious Ethics 20 (2013).

This Article is brought to you for free and open access by the Faculty Scholarship at Scholarly Commons. It has been accepted for inclusion in GW Law Faculty Publications \& Other Works by an authorized administrator of Scholarly Commons. For more information, please contact spagel@law.gwu.edu. 


\title{
JUSAD BELLUM, VALUES, AND THE CONTEM PORARY STRUCTURE OF INTERNATIONAL LAW
}

\author{
41 J ournal of Religious E thics 20 (2013)
}

\section{Sean D. M urphy \\ G eorge W ashington University L aw School}

IN RELIGION, VIOLENCE, AND HUMAN RIGHTS: Protection of Human Rights as J ustification for the $U$ se of Armed F orce, James J ohnson provides a typically lucid discussion of an important dilemma for contemporary society: when should transnational military force be permitted, as a matter of law, policy, and ethics, to protect against a widespread deprivation of human rights? Professor J ohnson uses the relatively recent concept of a "responsibility to protect" as the centerpiece of his paper, with his principal thesis being that any transnational use of force has implications both for the protection of human rights and for the denial of human rights. In other words, while the relevant rules of international law might be loosened so as to allow military force to protect human rights, it must be recognized that the legal prohibition on transnational uses of force is intended, in large part, to help protect persons from the death and destruction that invariably flow from any resort to war.

That cautionary admonition is sound and reflects why the doctrine of "responsibility to protect" has not been generally accepted to date by governments as a basis for authorizing uses of force by a state acting on its own authority. While I share the general thrust of J ohnson's thesis, I place the doctrine of "responsibility to protect" in a somewhat different context. In my

Sean D. M urphy received his B .A . from Catholic University and law degrees from Columbia U niversity, Cambridge University, and the University of V irginia. He is the Patricia R oberts Harris Research Professor of Law at George W ashington University and author of H umanitarian Intervention: The U nited Nations in an E volving World Order (1996). Sean D. M urphy, M ember, U N International Law Commission, Patricia Roberts Harris Research Professor of L aw, George W ashington University Law School, 2000 H Street, N.W., W ashington, D.C. 20052, smurphy@law.gwu.edu. 
view, the doctrine, as it relates to the use of military force, is not a reaction to the "W estphalian system" but, rather, a reaction to the UN Charter, particularly its relegation to the Security Council of the authority to determine when military force should be used for purposes other than self-defense.

The construction of sovereign states in the period surrounding the Peace of W estphalia in 1648 did not result in a system of international law that forbade the use of military force except in self-defense. There is nothing in the classic writings of the "founders" of international lawsuch as V itoria, Suarez, Gentili, or Grotius - or in their successors- such as V attel or Pufendorf - that limited the transnational use of force to self-defense. Rather, these writers accepted that the principle of "sovereignty" did not mean that one state was legally barred from interfering in the affairs of another state; any state was well within its rights to wage war against another state for reasons other than self-defense.

Grotius, for example, asserted that a state may resort to war (under both natural law and the law of nations) whenever doing so was based on a just cause, such as defense against an injury, recovery of what was legally due, or the infliction of punishment on a wrongdoing state for excessive crimes (G rotius 1925, Bk. II, chap. i, para. 2.2). W ith respect to excessive crimes, Grotius maintained that states have the right to punish other sovereigns not only for injuries to themselves or their own subjects, but also "on account of injuries which do not directly affect them but excessively violate the law of nature or of nationals in regard to any persons whatsoever" (Grotius 1925, Bk. II, chap. xx, para. 2.1). For Grotius, if a ruler "should inflict upon his subjects such treatment as no one is warranted in inflicting," other rulers may exercise a "right vested in human society" to undertake war on behalf of those subjects (Grotius 1925, B k. II, chap. xxv, para. 8). 
For some three hundred years, the idea that one state may resort to war against another state for reasons other than self-defense was fully accepted in international law. Though the term "humanitarian intervention" was not commonly used and "responsibility to protect" was never used, one can discern such thinking in both the writers of the time and the practice of states. For instance, several interventions by the Concert of Europe to protect Christian minorities in the outer orbit of the decaying Ottoman Empire were viewed by key statesmen (such as William Gladstone) and writers (such as J ohn Stuart M ill) as permissible intervention for the purpose of protecting oppressed peoples (Holbraad 1970, 162-76). That practice led the French scholar A ntoine Rougier to write the first exhaustive and highly influential article on humanitarian intervention, in which he advocated in favor of collective intervention by a group of "disinterested" states, but only when exceptionally serious violations are occurring (R ougier 1910). Hence, the reason rules on the conduct of warfare (jus in bello) that begin to be systematically codified in the 1800s- especially after the 1863 Li ieber Code (developed for the U.S. Union A rmy), which heavily influenced the 1899 and 1907 Hague Conventions-say nothing about "humanitarian intervention" or "responsibility to protect" is that the prevailing law at the time did not bar states from militarily intervening in other states, whether for that reason or for less altruistic purposes, such as seizing and annexing territory, a recurrent feature of interstate relations in the nineteenth century.

Only in the twentieth century did the idea of outlawing war emerge, notably with the $1928 \mathrm{G}$ eneral Treaty for the R enunciation of W ar (commonly referred to as the K ellogg-Briand Pact), by which the states' Parties declared that "they condemn recourse to war for the solution of international controversies, and renounce it, as an instrument of national policy in their relations with one another" (K ellogg-B riand Pact, §1). The Pact (along with the League of 
Nations) faded away with the rise of the A xis Powers, but the idea of the Pact did not fade; it was center stage at the 1944 meeting of the A llied Powers at Dumbarton Oaks, convened for the purpose of crafting what would become the U nited Nations Charter. A rticle 2.4, perhaps the most important provision of the Charter, provides: "All members shall refrain in their international relations from the threat or use of force against the territorial integrity or political independence of any state, or in any other manner inconsistent with the Purposes of the U nited Nations" (K ellogg-B riand Pact, §2.4).

There are two important exceptions to A rticle 2.4. First, A rticle 51 provides that nothing in the "Charter shall impair the inherent right of individual or collective self-defense if an armed attack occurs against a $\mathrm{M}$ ember of the U nited $\mathrm{N}$ ations, until the Security Council has taken measures necessary to maintain international peace and security" (K ellogg-B riand Pact, §51). Second, under Chapter V II of the Charter, the Security Council may determine that there exists a threat to the peace, a breach of the peace, or an act of aggression (§39), and may decide upon either non-forcible (\$41) or forcible (\$42) measures as necessary to restore peace and security.

A s such, the structure of international law concerning the legality of resorting to war (jus ad bellum) embodied in the UN Charter prohibits states from resorting to a transnational use of force unless they are acting in self-defense or pursuant to authorization from the UN Security Council. For most international lawyers, this structure was the seminal achievement of international law in the twentieth century. Prior to 1945, transnational warfare was relatively common, with horrendous consequences. A fter 1945, transnational warfare is not unknown, but is rare, and when it occurs is immediately condemned. States no longer invade and annex other states. 
Given that by late J une 1945, when the UN Charter was adopted, the atrocities committed by $\mathrm{N}$ azi Germany against its own people were known, why did the Charter not al so permit states to use transnational force to prevent such atrocities? First, while the fact of the atrocities committed by the $\mathrm{N}$ azi regime were known from the liberation of concentration camps by Allied forces, the full extent of those atrocities was not fully understood, certainly not during the period when the Charter was being drafted. The "age of human rights" would only commence a few years later; references to such rights in the Charter are few and far between. Second, the A xis Powers themselves had masked some of their aggression as "humanitarian" interventions, notably J apan's invasion of M anchuria in 1931, Italy's invasion of Ethiopia in October 1935, and Germany's occupation of B ohemia and M oravia in 1939, all purportedly undertaken for the protection of the local population. A rticle 2.4, therefore, was designed to shut the door on aggression undertaken for "good causes." Third, the UN Charter did not limit uses of transnational force only to situations involving self-defense; it established an organ capable of reflecting collective decision-making - a "sovereign above sovereigns" - in the form of the Security Council to address any "threat to the peace." W hile that concept no doubt originally was viewed as focused on transnational threats to the peace, in fact the concept was not so limited, and as early as the 1960s was viewed as embracing Security Council action to impose a coercive embargo on the white racist regime in Southern R hodesia for internal actions. Thus, to the extent that humanitarian intervention was necessary, it could be undertaken within the strictures of the UN Charter, so long as it was authorized by Security Council.

Why, then, did the concept of a "responsibility to protect" suddenly emerge in the late 1990s? During the Cold W ar, the Security Council was usually deadlocked on the issue of authorizing any military force, not just force for humanitarian purposes. W hile there were some 
calls for greater resort to military force, even in the absence of Security Council authorization, for humanitarian or other purposes, those voices were a minority and non-governmental. The confrontation between the East and W est, undertaken in the shadow of nuclear weapons, made the stakes far too high for playing around with rules on the transnational use of military force. A fter the Cold W ar ended, great hopes arose for a "new world order" in which the Security Council would awaken from its slumber and become actively engaged in addressing threats to the peace. In fact, the Security Council did awaken, authorizing military force to address transnational threats to the peace, such as Iraq' s invasion of K uwait in 1990-91, and internal threats to the peace, such as to end famine in Somalia in 1992, and to restore Haiti's democratically-elected government in 1993-94. Even in Rwanda, often pointed to as an example of global inaction, it is often forgotten that France was authorized by the Council to intervene in 1994, though it proved to be too little and too late.

Then came K osovo. The Security Council could have authorized military action to suppress Serbian conduct in the province of K osovo, but resistance by two permanent members - China and Russia - precluded any such action. In 1999, NATO decided to go forward anyway, bombing Serbia for several weeks until B elgrade agreed to withdraw all military and police units from its province. For many observers, this was a natural evolution in international law; intervention to protect persons facing a widespread deprivation of human rights should normally be authorized by the Security Council but, if the Council could not act due to the veto of a permanent member, then the intervention should go forward anyway.

Thus was born the doctrine of "responsibility to protect." The International Commission on Intervention and State Sovereignty (ICISS), a group of non-governmental experts convened by the Government of Canada, issued in December 2001 a report entitled The Responsibility to 
Protect, which sought to provide a legal and ethical foundation for humanitarian intervention. The report asserted that a responsibility to protect (or "R2P") exists under international law. Further, the report stated that in circumstances when the Security Council fails to discharge that responsibility, "in a conscience-shocking situation crying out for action," then it "is a real question in these circumstances where lies the most harm: in the damage to international order if the Security Council is bypassed or in the damage to that order if human beings are slaughtered while the Security Council stands by" (ICISS 2001, para. 6.37). The doctrine was born not out of a rejection of the Westphalian system of sovereignty; it was a cautious rebellion against the UN Charter's jus ad bellum straightjacket, which granted a monopoly to the Security Council for deciding when transnational force may be used for purposes other than self-defense.

As J ohnson notes, the contours of the R 2P doctrine are not entirely clear and have been subject to considerable scrutiny and dispute (Focarelli 2008; Stahn 2007). Y et one thing seems rather clear-governments have not welcomed the doctrine with open arms, at least not the bit that favors transnational uses of force in the absence of Security Council authorization. The postK osovo wave of enthusiasm for the doctrine crashed upon the shores of the U.S.-led invasion of Iraq in 2003, in which the U nited States could not obtain Security Council authorization to invade, but went forward anyway, justifying its action in part by reference to I raq's mistreatment of its nationals (B ush 2003) and the need to help liberate the Iraqi people (Slevin 2002). By 2004, a U N high-level panel convened by Secretary-General K ofi A nnan saw things a bit different than the ICISS. W hile the high-level panel agreed that there existed an "emerging norm that there is a collective international responsibility to protect," it concluded that armed force may be used to ensure fulfillment of that responsibility only if so authorized by the Security Council (A nnan 2004, para. 196, 203, and 272). Further, the high-level panel identified five 
criteria of "legitimacy" when engaging in such intervention, including to the seriousness of the threat, the proper purpose of the interveners, the exhaustion of other means, proportionality, and a balancing of the ensuing consequences (A nnan 2004, para. 207). The UN Secretary-General thereafter endorsed the high-level panel's approach, an approach that continues to reflect the view of the Secretary-General today.

When calls are made to uphold a "responsibility to protect" - whether coming from groups such as the Conference of Catholic B ishops or other A merican religious bodies- it is not al ways clear if this means just action through the Security Council or action even in the face of opposition within the Security Council. If the former, then it is not a call for an armed attack on a state in violation of the UN Charter; rather, it is a call for action fully consistent with the purposes and principles of the Charter and the institutions it has created. It is a call for the Security Council to step up and do what it was created to do. $Y$ et, if the latter, then perhaps there are certain values that are being ignored, as J ohnson cautions. One val ue derives from collective decision-making, which may minimize the likelihood of aggression masked as altruism. The Security Council may not be a perfect institution, but it consists of five of the major powers of the world plus another ten countries elected so as to represent the different regions of the world. Their collective view that the human rights at stake in a particular situation merit military intervention has certain advantages over the decision-making by a single state or a small group of states. A nother value is the need to preserve peace among the major powers of the world; as it happens, the permanent members of the Security Council all have very significant military capability, including the possession of nuclear weapons. A s a general proposition, it is risky for some of those members to pursue military action in the face of strong opposition by one or more of the other permanent members. While in this relative time of peace, it may seem unlikely that a 
purportedly humanitarian intervention would escalate into a military confrontation among those powers, that low likelihood must be weighed against the catastrophe that such a confrontation would yield.

\section{REFERENCES}

A nnan, Kofi A.

2004 A M ore Secure World: O ur Shared Responsibility: Report of the High-level Panel on Threats, Challenges and Change. UN Doc. A/59/565. A vailable at: http://www.un.org/secureworld/report.pdf (accessed A ugust 8, 2012).

Bush, George 2003 Address to the Nation on Iraq. 39 W eekly Comp. Pres. Doc. 338, M ar. 17.

Focarelli, Carlo

2008 "The Responsibility to Protect Doctrine and Humanitarian Intervention: Too M any A mbiguities for a W orking Doctrine." J ournal of Conflict and Security Law 13.2: 191-213.

Grotius, Hugo

1925 De Jure Belli ac Pacis Libri Tres ( $\mathrm{n}$ the Law of War and Peace). Translated by F. K elsey. Washington, D.C.: Carnegie Classics of International Law.

Holbraad, Carsten

1970 The Concert of Europe: A Study in German and British International Theory, 1815-1914. London: Longmans.

International Commission on Intervention and State Sovereignty (ICISS)

$2001 \quad$ "The Responsibility to Protect." Co-chaired by Gareth Evans and M ohamed Sahnoun. Ottawa, Canada: International D evelopment Research Centre.

K ellogg, Frank B., and A ristide Briand 1928 K ellogg-B riand Pact: General Treaty for the Renunciation of W ar. 46 Stat. 2343, 94 L.N.T.S. 57.

Rougier, A ntoine

1910 "La théorie de l'intervention d'humanité." In Revue générale de D roit International Public 17.1: 468-526.

Slevin, Peter

2002 "Powell Casts A ttack on Iraq as 'Liberation': U.S. W ould Emphasize Democracy, 'New Era.'" Washington Post, Sept. 20. 
Stahn, Carsten

2007 "Responsibility to Protect: Political Rhetoric or Emerging Legal Norm?" The American J ournal of International Law 101.1: 99-120. 